\title{
Tata Kelola Wakaf dalam Meningkatkan Kesejahteraan Masyarakat di Kabupaten Jember
}

\author{
Abd. Syakur \\ (Fakultas Ilmu Sosial dan Politik Universitas Negeri Jember, Jln. Kalimantan 37 \\ Jember, Email: syakurjember@gmail.com) \\ Hary Yuswadi \\ (Fakultas Ilmu Sosial dan Politik Universitas Negeri Jember, Jln. Kalimantan 37 \\ Jember, Email: syakurjember@gmail.com)

\section{Bagus Sigit Sunarko} \\ (Fakultas Ilmu Sosial dan Politik Universitas Negeri Jember, Jln. Kalimantan 37 \\ Jember, Email: syakurjember@gmail.com)

\section{Edy Wahyudi} \\ (Fakultas Ilmu Sosial dan Politik Universitas Negeri Jember, Jln. Kalimantan 37 \\ Jember, Email: syakurjember@gmail.com)
}

\begin{abstract}
Abstrak
Wakaf memiliki kontribusi solutif untuk mengatasi persoalan sosial ekonomi masyarakat. Namun realitanya, potensi tanah wakaf di Kabupaten Jember yang mencapai 141, 06 hektar yang tersebar di 1.495 lokasi masih dikelola secara tradisional. Penelitian ini difokuskan pada implementasi kebijakan wakaf dalam meningkatkan kesejahteraan masyarakat, faktor-faktor penghambat, serta alternatif solusi untuk mengatasinya. Penelitian ini menggunakan metode deskriptif kualitatif. Hasil penelitian ini yaitu tata kelola wakaf di Kabupaten Jember belum terlaksana dengan baik, yang disebabkan karena belum dibentuknya BWI; ego ahli waris dari wakif yang ingin menguasai tanah wakaf dan merasa tidak cocok dengan nâzhir; sistem kenâzhiran yang kurang professional; kurangnya sosialisasi kebijakan wakaf; dan diperparah dengan ketidak-patuhan sebagian masyarakat terhadap kebijakan wakaf. Oleh karena itu, setiap nâzhir perlu mewujudkan Good Waqf Governance dengan menerapkan prinsip-prinsip Good Corporate Governance (GCG) berbasis Islam, karena GCG konvensional saja tidak cukup apabila tidak didukung dengan pelaku-pelaku yang jujur dan amanah.
\end{abstract}

al-1hkâm Vol.13 No.1 Juni 2018

DOI 10.19105/al-ihkam.v13i1.1187 
Abd. Syakur, dkk.

Kata Kunci:

Implementasi Kebijakan, Tata Kelola, Wakaf, Kesejahteraan Masyarakat

\begin{abstract}
Wakaf has a solute contribution to overcome the socio-economic problems of the community. However, the potential of waqf land in Jember which reaches 141.06 hectares spread over 1,495 locations is still managed traditionally. This research is focused on the implementation of wakaf policy in improving community welfare, inhibiting factors, and alternative solutions. This study used descriptive qualitative method. The result of this research is that the management of waqf in Jember is not well implemented, which is caused by the lack of establishment of BWI; the wishes of the heirs of the wakif who want to control the land of waqf and feel incompatible with nâzhir; less professional system of kenâzhiran; lack of socialization of wakaf policy; and the non-compliance of some people to the wakaf policy. Therefore, every nâzhir needs to realize Good Waqf Governance by applying the principles of Good Corporate Governance (GCG) based on Islam, because conventional GCG alone is not enough if it is not supported by honest and trustful actors.
\end{abstract}

\title{
Keywords:
}

Policy Implementation, Governance, Waqaf, Public Welfare

\section{Pendahuluan}

Wakaf merupakan salah ibadah berupa pengorbanan sebagian harta. Jika dilihat dari segi pengorbanan maka wakaf sepertinya identik dengan zakat. Namun, sebenarnya memiliki perbedaan. Seperti yang dikemukakan Setiawan, bahwa ciri utama dari wakaf adalah ketika wakaf itu telah ditunaikan maka terjadi pergeseran kepemilikan pribadi (private) menjadi kepemilikan masyarakat (public) yang diharapkan mampu memberikan manfaat secara berkelanjutan. Wakaf sebagai instrumen pendistribusian manfaat bagi masyarakat secara lebih luas atau menggeser 'private benefit' menjadi 'social benefit'. ${ }^{1}$ Wakaf sebagai satu instrumen ekonomi dalam kehidupan muslim yang mempunyai tujuan untuk mensejahterakan masyarakat. Wakaf juga dipandang sebagai bentuk instrumen unik yang lebih

${ }^{1}$ Budi Utomo Setiawan, Fiqh Aktual, (Jakarta: Gema Insani Press, 2004), 67. 
mendasarkan pada unsur kebijakan (birr), kebaikan (ihsan) dan persaudaraan (ukhuwah). Sehingga mengeluarkan wakaf selain beribadah juga mempunyai dimensi membantu saudara yang membutuhkan.

Di Indonesia, wakaf telah dikenal oleh umat Islam sejak agama Islam masuk Indonesia pada pertengahan abad XIII. Wakaf telah banyak membantu pembangunan secara menyeluruh di Indonesia, baik dalam pembangunan sumber daya manusia maupun dalam pembangunan sumber daya sosial. Tak dapat dipungkiri bahwa sebagian besar rumah ibadah dan lembaga-lembaga Islam lainnya dibangun di atas tanah wakaf. Menurut data dari Kementerian Agama, aset nasional ekonomi wakaf sangat besar mencapai 590 Triliun, jika dilihat dari angka rata-rata aset lembaga wakaf dikalikan dengan jumlah lokasi wakaf. ${ }^{2}$

Wakaf mempunyai kontribusi solutif terhadap terhadap kesejahteraan masyarakat, khususnya persoalan sosial-ekonomi kemasyarakatan. Kalau dalam tataran ideologis wakaf berbicara tentang bagaimana nilai-nilai yang seharusnya diwujudkan oleh dan untuk umat Islam, maka pada wilayah sosial-ekonomis, wakaf telah menjadi satu jawaban konkrit dalam realitas problematika kehidupan (sosial-ekonomis) masyarakat. Fungsi sosial dari perwakafan tanah mempunyai arti bahwasanya penggunaan hak milik tanah seseorang harus memberi manfaat secara langsung atau tidak langsung kepada masyarakat. Dalam ajaran kepemilikan harta dalam Islam, bahwasanya harta yang menjadi milik seseorang ada hak orang lain yang melekat pada harta benda tersebut.

Menurut data yang dirilis oleh Kementerian Agama RI, jumlah lokasi tanah wakaf di Indonesia sebanyak 336.466 lokasi dengan luas tanah 49.608,72 hektar, meliputi 19.099,59 hektar sudah tersertifikat dan 30.509,13 hektar belum tersertifikat. Dari seluruh tanah wakaf yang tersebar di Indonesia tersebut $44,96 \%$ dimanfaatkan sebagai masjid; $28,79 \%$ sebagai mushola; $10,41 \%$ sebagai sekolah/madrasah; $4,62 \%$ sebagai makam; $2,98 \%$ sebagai pesantren; dan 8,24 sebagai

2 BWI, "Tantangan Wakaf untuk Keadilan Sosial”, 2 Desember 2008, https:// bwi.or.id/index.php/ar/publikasi/berita-mainmenu-109/346-tantanganwakaf-untuk-keadilan-sosial.html, (diakses tanggal 23 Februari 2018). 
sarana prasarana sosial lainnya. ${ }^{3}$ Sedangkan, khusus aset tanah wakaf di Kabupaten Jember saja keseluruhannya adalah 141,06 hektar yang tersebar di 1.495 lokasi, sudah tersertifikasi seluas 24,12 hektar, dan 116,93 hektar belum tersertifikasi.4 Berdasarkan data di lapangan wakaf tersebut kebanyakan pengelolaannya masih bersifat tradisional yaitu untuk pembangunan masjid, mushola, madrasah, panti asuhan, dan makam.

Menurut Abu Azam Al-Hadi, beberapa hal berikut seharusnya menjadi perhatian berbagai pihak dalam pengelolaan wakaf. Pertama, perhatian yang lebih besar bagi pemberdayaan wakaf yang belum produktif, mayoritas berbasis masjid dan lembaga pendidikan serta memberdayakan wakaf yang masih terlantar. Kedua, peningkatan sumber daya manusia berkaitan dengan persoalan manajemen dan profesionalisme serta keahlian mengoptimalkan potensi ekonomi wakaf perlu menjadi prioritas. Ketiga, bersama-sama dengan lembaga nasional dan internasional penting memikirkan upaya pengembangan ekonomi wakaf dengan membuka jalur investasi pada wakaf yang strategis dan potensial. Keempat, hendaknya membangun kepercayaan publik (public trust) dengan meningkatkan standar akuntabilitas dan transparansi lembaga wakaf. Kelima, pembuatan regulasi wakaf hendaknya didorong untuk mendukung pengembangan wakaf untuk tujuan keadilan sosial. ${ }^{5}$ Oleh karena itu, upaya pengembangan wakaf harus dilakukan dengan pola yang integratif dan terencana, sehingga wakaf dapat dikelola secara optimal dan memberi manfaat yang lebih luas bagi kepentingan sosial. Berbagai upaya tersebut, salah satunya harus dipelopori oleh para pejabat teknis yang ada di lingkungan Kementerian Agama.

\footnotetext{
${ }^{3}$ Direktorat Pemberdayaan Zakat dan Wakaf Kementerian Agama RI, "Jumlah Tanah Wakaf Seluruh Indonesia", http://siwak.kemenag.go.id/tabel_jumlah_tanah_wakaf.php, (diakses tanggal 22 Februari 2018).

4 Direktorat Pemberdayaan Zakat dan Wakaf Kementerian Agama RI, "Jumlah Tanah Wakaf Seluruh Indonesia", http://siwak.kemenag.go.id/tanah_wakaf_kab.php?prov=35\&kab=09, (diakses tanggal 22 Februari 2018).

5 Abu Azam Al-Hadi, "Upaya Pemberdayaan Tanah Wakaf Produktif Bagi Kesejahteraan Ummat,” Jurnal Islamica, Vol. 4 No. 1, (September, 2009),. 95.
} 
Winajat ${ }^{6}$ mengatakan bahwa sejalan dengan kedudukan wakaf sebagai salah satu macam sedekah. Harta wakaf terlepas dari hak milik wakif (orang yang mewakafkan) dan tidak pula pindah menjadi milik orang-orang atau badan-badan yang menjadi tujuan wakaf. Harta wakaf terlepas dari hak milik wakif sejak wakaf diikrarkan dan menjadi hak penerima wakaf. Dengan demikian harta wakaf menjadi amanat di tangan pengawas (nâzhir).

Kurniawati7 juga menjelaskan bahwa menurut al-Syafii tidak boleh menarik kembali harta yang telah diwakafkan meskipun itu digunakan untuk kepentingan yang baik. Penarikan kembali yang dilakukan oleh orang yang mewakafkan tidak diperkenankan dalam Islam karena harta tersebut bukan hak miliknya.

Informan dalam penelitian ini adalah ahli waris yang mengambil kembali harta tersebut. Ahli waris memiliki hak untuk memiliki harta atau tanah sesuai dengan bagian yang telah ditentukan. Kasus yang ditemukan tersebut adalah bahwa harta ini bisa diambil kembali karena tidak memiliki bukti tertulis atau AIW (Akta Ikrar Wakaf). Jika tanah tidak memiliki bukti tertulis maka tidak memiliki kekuatan hukum. Faktor yang mempengaruhi hal tersebut adalah masalah ekonomi dan kurangnya pengetahuan agama.

Penelitian ini menggunakan teori Implementasi Kebijakan Publik, teori Hak Kepemilikan, serta teori Good Corporate Governance (GCG). Grindle menyatakan bahwa implementasi merupakan proses umum tindakan administratif yang dapat diteliti pada tingkat program tertentu. Ia juga menambahkan bahwa proses implementasi baru akan dimulai apabila tujuan dan sasaran telah ditetapkan, program kegiatan telah tersusun dan dana telah siap dan telah disalurkan untuk mencapai sasaran. ${ }^{8}$ Friedrich mendefinisikan kebijakan sebagai serangkaian tindakan yang diusulkan seseorang, kelompok atau pemerintah dalam suatu lingkungan tertentu dengan menunjukkan hambatan dan kesempatan-kesempatan terhadap

${ }^{6}$ Uden Winajat, "Sertifikasi Tanah Wakaf di Kecamatan Warungkondang Kabupaten Cianjur”, (Tesis, STAIN Salatiga, 1996), 32.

${ }^{7}$ Lia Kurniawati, "Penarikan Wakaf Tanah oleh Ahli Waris (Studi Kasus di Kelurahan Manding Kecamatan Temanggung)”, (Tesis, STAIN Salatiga, 2012), 98.

${ }^{8}$ Merilee S. Grindle, Politics and Policy Implementation in the Third World, (New Jersey: Princeton University Press, 1980), 7. 
pelaksanaan usulan kebijakan tersebut dalam rangka mencapai tujuan tertentu. ${ }^{9}$

Implementasi kebijakan menghubungkan antara tujuan kebijakan dan realisasinya dengan hasil kegiatan pemerintah. Hal ini sesuai dengan pandangan Grindle bahwa tugas implementasi adalah membangun jaringan yang memungkinkan tujuan kebijakan publik direalisasikan melalui aktivitas instansi pemerintah yang melibatkan berbagai pihak yang berkepentingan (policy stakeholders). Dari definisi yang telah diuraikan tersebut, menekankan implementasi tidak hanya melibatkan perilaku badan-badan administrasi yang bertanggungjawab untuk melaksankan program dan menimbulkan ketaatan pada diri kelompok sasaran, tetapi juga menyangkut jaringan kekuatan politik, ekonomi, dan sosial yang dapat mempengaruhi perilaku dari semua pihak yang terlibat dan akhirnya berdampak pada diharapkan maupun yang tidak diharapkan dari suatu program. ${ }^{10}$

Menurut Grindle terdapat dua variabel besar yang mempengaruhi implementasi kebijakan, yaitu isi kebijakan (content of policy) dan lingkungan implementasi (context of implementation). Masing-masing variabel tersebut masih dipecah lagi menjadi beberapa item. Variabel isi kebijakan ini mencakup (1) sejauh mana kepentingan kelompok sasaran atau target groups termuat dalam isi kebijakan; (2) jenis manfaat yang diterima oleh target group; (3) sejauh mana perubahan yang diinginkan dari sebuah kebijakan; (4) apakah letak sebuah program sudah tepat; (5) apakah sebuah kebijakan telah menyebutkan implementornya dengan rinci; (6) apakah sebuah program didukung oleh sumber daya yang memadai. Sedangkan variabel lingkungan kebijakan mencakup: (1) seberapa besar kekuasaan, kepentingan, dan strategi yang dimiliki oleh para aktor yang terlibat dalam implementasi kebijakan; (2) karakteristik institusi dan rejim yang sedang berkuasa; (3) tingkat kepatuhan dan responsivitas kelompok sasaran. ${ }^{11}$

Kebijakan publik merujuk pada konsep untuk menjelaskan

\footnotetext{
${ }^{9}$ Hessel Nogi S. Tanguilisan, Teori dan Konsep Kebijakan Publik, (Yogyakarta: Ar-Ruzz Media, 2004), 1.

10 Grindle, Politics and Policy Implementation, 6.

11 Ibid., 6-10.
} 
pilihan-pilihan tindakan tertentu yang spesifik, seperti pada bidangbidang tertentu dalam sektor-sektor fasilitas umum, transportasi, pendidikan, kesehatan, perumahan atau kesejahteraan. Sebagai contoh, kebijakan sosial secara ringkas dapat diartikan sebagai salah satu bentuk kebijakan publik yang mengatur urusan kesejahteraan. Kesejahteraan dalam hal ini erat kaitannya dengan perekonomian. Konsep yang penting dalam perekonomian adalah konsep kepemilikan. Kepemilikan menjadi posisi penting dari teori ekonomi mikro, baik dalam sistem ekonomi Islam maupun kapitalis karena pembahasan dalam bidang kepemilikan tidak hanya berkaitan dengan aspek ekonomi belaka, tetapi juga aspek sosial dan politik sehingga menjadi perhatian penting para pemikir ekonomi Islam dan konvensional sampai saat ini.

Bromley mencatat empat jenis kepemilikan, yaitu: milik negara, milik bersama, milik privat, dan bukan milik siapa-siapa. ${ }^{12}$ Dari keempat jenis kepemilikan tersebut, hanya kepemilikan oleh privat yang bisa dikonsumsi secara eksklusif dan bias ditransfer pada orang lain. Sedangkan sumber daya milik negara dan milik bersama, tidak bisa dieksklusifkan pengonsumsiannya pada orang-orang tertentu saja. Wakaf merupakan salah satu contoh tentang hak milik bersama/kolektif, yaitu ketika sebuah harta kekayaan disumbangkan untuk tujuan tertentu atau untuk kelompok masyarakat tertentu, maka ada kewajiban bahwa harta tersebut harus digunakan sesuai dengan maksudnya. Namun, Ibnu Taimiyah berpendapat bahwa harta wakaf bisa digunakan untuk kepentingan lain apabila memberi manfaat yang lebih besar. ${ }^{13}$

Penulis juga menggunakan perspektif teori Good Corporate Governance (GCG). GCG pada dasarnya merupakan suatu sistem dan seperangkat peraturan yang mengatur hubungan antara berbagai pihak yang berkepentingan (stakeholders) terutama dalam arti sempit hubungan antara pemegang modal dan dewan pengelola demi tercapainya tujuan organisasi. GCG dimasukkan untuk mengatur hubungan-hubungan ini dan mencegah terjadinya kesalahan-

12 Daniel Bromley, Economic Interests and Institutions, (New York: Basil Blackwell, 1989), 98.

13 Abdullah Abdul Husain at-Tariqi, Ekonomi Islam: Prinsip, Dasar dan Tujuan, (Yogyakarta: Magistra Insania Press, 2004), 143. 
kesalahan signifikan dalam strategi organisasi dan untuk memastikan bahwa kesalahan-kesalahan yang terjadi dapat diperbaiki dengan segera. ${ }^{14}$ GCG terdiri dari prinsip: Transparancy, Accountability, Responsibility, Independency, dan Fairness. Transparancy diartikan sebagai keterbukaan dalam mengemukakan informasi yang material dan relevan serta keterbukaan dalam melaksanakan proses pengambilan keputusan. Accountability yaitu kejelasan fungsi dan pertanggung-jawaban sehingga pengelolaannya berjalan efektif. Responsibility yaitu kesesuian pengelolaan dengan peraturan perundang-undangan yang berlaku dan prinsip-prinsip yang sehat. Independency yaitu pengelolaan secara profesional tanpa pengaruh/tekanan dari pihak manapun. Dan Fairness yaitu keadilan dan kesetaraan dalam memenuhi hak-hak stakeholder. ${ }^{15}$

Dengan demikian, maka dapat dipahami bahwa wakaf mempunyai kontribusi solutif terhadap persoalan-persoalan sosial ekonomi kemasyarakatan dalam arti wakaf tanah mengandung potensi sumber daya ekonomi umat. Wakaf dalam tataran idiologis berbicara tentang bagaimana nilai-nilai yang seharusnya diwujudkan oleh dan untuk umat Islam, sedangkan pada wilayah paradigma sosial-ekonomis, wakaf menjadi jawaban konkrit dalam menghadapi realitas problematika kehidupan masyarakat. Salah satu konsep sumber daya ekonomi apabila dikaitkan dengan tanah mungkin dapat dipahami, bahwa tanah merupakan natural resources (sumber daya alam), sedangkan manusia sebagai human resources (sumber daya manusia).

\section{Metode Penelitian}

Metode penelitian yang digunakan adalah deskriptif kualitatif. Metode deskriptif kualitatif adalah metode penelitian yang bertujuan membuat deskripsi atas suatu fenomena sosial atau fenomena alam secara sistematis, faktual dan akurat. ${ }^{16}$ Lokasi penelitian ini di Kabupaten Jember, yang difokuskan di Kecamatan Jombang,

14 W Zarkasyi, Good Corporate Governance Pada Badan Usaha Manufaktur, Perbankan, dan Jasa Keuangan Lainnya, (Bandung: Alfabeta, 2008), 98.

${ }^{15}$ Komite Nasional Kebijakan Governance (KNKG), Pedoman Umum Good Corporate Governance Indonesia, (Jakarta: KNKG, 2006), 34-45

16 Matthew B. Miles and Huberman, Analisis Data Kualitatif: Buku Sumber Tentang Metode-metode Baru, (terj.) Tjetjep Rohendi Rohidi, (Jakarta: UI-Press, 1992),. 15-16. 
Tempurejo, dan Gumukmas. Lokasi tersebut dipilih karena beberapa alasan, yaitu: Dari aspek luasnya tanah, ketiga lokasi tersebut mempunyai potensi tanah wakaf yang terbesar di antara kecamatan yang lain. Luas tanah wakaf di Kecamatan Jombang seluas 26,21 hektar, Kecamatan Gumukmas seluas 31,92 hektar, dan Kecamatan Tempurejo seluas 12,40 hektar. ${ }^{17}$

Dalam penelitian ini, penentuan informan yang digunakan dengan teknik purposive. Teknik Purposive adalah teknik pengambilan informan dengan beberapa pertimbangan tertentu. ${ }^{18}$ Pertimbanganpertimbangan tersebut diantaranya yaitu informan yang memahami dan melaksanakan pengelolaan wakaf di Kabupaten Jember. Informan yang dipilih diantaranya: Kepala Kementerian Agama Kabupaten Jember, Kepala KUA, nâzhir, dan wakif di Kecamatan Tempurejo, Gumukmas, dan Jombang. Prosedur pengumpulan data yang dilakukan dalam penelitian ini menggunakan instrumen wawancara, observasi, dan studi dokumenter.

Adapun analisis data menggunakan analisis kualitatif yang terdiri dari tiga alur kegiatan yang terjadi secara bersamaan, yaitu: data condensation (kondensasi data), data display (penyajian data), dan conclusion drawing/verifications (penarikan kesimpulan). ${ }^{19}$ Dalam penelitian ini juga menggunakan beberapa kriteria untuk memeriksa keabsahan data yaitu: memperpanjang masa observasi, melakukan peerdebriefing, triangulasi, dan mengadakan member check. ${ }^{20}$

\section{Hasil Penelitian}

\section{Implementasi Kebijakan Tata Kelola Wakaf di Kabupaten Jember}

Sebelum berlakunya Undang-Undang No. 41 Tahun 2004 tentang wakaf, lahirlah peraturan lainya yang juga mengatur

\footnotetext{
17 Direktorat Pemberdayaan Zakat dan Wakaf Kementerian Agama RI, "Jumlah Tanah Wakaf Seluruh Indonesia", http://siwak.kemenag.go.id/tanah_wakaf_kab.php?prov=35\&kab=09, (diakses tanggal 22 Februari 2018).

18 Sugiyono, Metode Penelitian Kuantitatif, Kualitatif Dan RED, (Bandung: Alfabeta, 2008),. 218.

19 Metthew B. Miles, A. Michael Huberman, and Johnny Saldana, Qualitative Data Analysis, A Methods Sourcebook, (Sage Publications, Inc., 2014),. 31-33.

20 Sugiyono, Metode Penelitian,. 302-305.
} 
keberadaan wakaf tersebut yaitu diantaranya diberlakunya Peraturan Pemerintah No. 28 Tahun 1977, dimana dalam dalam PP ini memberikan pengertianya mengenai wakaf yang disebutkan dalam pasal 1 ayat (1) yang berbunyi "Wakaf adalah perbuatan hukum seseorang atau badan hukum yang memisahkan sebagian dari harta kekayaanya yang berupa tanah milik dan melembagakanya untuk selama-lamanya untuk kepentingan peribadatan atau keperluan umum lainya sesuai dengan ajaran agama Islam.

Namun, dalam perjalananya adanya ketentuan PP No. 28 Tahun 1977 ini ternyata dirasa masih kurang, lebih-lebih setelah melihat kebutuhan masyarakat para calon wakif yang hendak melakukan wakaf dalam jumlah nominal yang terbatas, mengingat PP ini hanya membatasi obyek wakaf hanya pada tanah hak milik saja yang tidak mencakup harta lainnya yang dimiliki oleh wakif.

Perjuangan untuk membuat payung hukum kegiatan wakaf dalam bentuk Undang-Undang terus digalakkan oleh berbagai kalangan. Akhirnya, pihak Pemerintah Indonesia mengeluarkan Undang-Undang No. 41 Tahun 2004 tentang Wakaf dan Peraturan Pemerintah Nomor 42 Tahun 2006 tentang pelaksanaan UndangUndang Nomor 41 Tahun 2004. Peraturan perundang-undang tersebut antara lain mengatur bentuk benda wakaf, yaitu benda tetap, dan benda tidak tetap dan uang. Hal ini dapat dilihat dalam ketentuan yang terdapat dalam Pasal 28 s/d 31 UU No 41 Tahun 2004 dan Pasal 22 s/d 27 PP No 42 Tahun 2006.

Pengelolaan wakaf tanah di Kabupaten Jember telah disesuaikan dengan peraturan-peraturan yang berlaku, walaupun sebagian besar dari tanah wakaf belum bersertifikat tanah wakaf atau belum terdaftar di Kantor Pertanahan, dalam arti masih ikrar wakaf secara lisan dan ada yang berbentuk Akta Ikrar Wakaf (AIW) saja, namun semuanya telah dilakukan sesuai dengan ketentuan yang ada. $^{21}$

Peranan Kementerian Agama Kabupaten Jember dalam perwakafan tanah sangat komplek, yaitu sebagai lembaga pemerintah yang menangani dan secara administratif berwenang untuk merubah atau mengalihkan tanah wakaf. Merubah/mengalihkan disini maksudnya bahwa tanah wakaf yang sudah bersertifikat kemudian

${ }^{21}$ Abdullah, Kabid. Wakaf KUA Jombang, wawancara, (tanggal 19 Januari 2017). 
dianggap oleh nâzhir sudah tidak dapat digunakan sesuai dengan peruntukannya lagi. Dalam hal ini Kementerian Agama mempunyai kewenangan untuk menyetujui dalam pengalihan tanah wakaf, sedangkan nâzhir hanya sebagai pengelola. Kementerian Agama berwenang menyatakan ini tanah wakaf atau bukan. Kantor Pertanahan kewenangannya hanya sekedar membuatkan bukti hak milik tanah wakafnya. 22

Dilihat dari segi pemanfaatannya, wakaf dibagi menjadi dua yaitu konsumtif-tradisional dan produktif. Wakaf konsumtiftradisional yaitu harta benda wakaf dipergunakan langsung untuk kepentingan umat. Pada umumnya wakaf digunakan untuk pembangunan masjid, mushalla, sekolahan, rumah yatim piatu, makam. Selama ini pemanfaatan wakaf dilihat dari segi sosial, khususnya untuk kepentingan peribadatan memang cukup efektif. Akan tetapi dampaknya kurang berpengaruh positif dalam kehidupan ekonomi masyarakat apabila peruntuikan wakaf hanya terbatas pada hal-hal tersebut.

Tanah-tanah wakaf yang ada di Kabupaten Jember dimanfaatkan sebagian besar masih dengan cara tradisional, seperti: pondok pesantren, masjid, mushola, dan madrasah, dan hanya sebagian kecil saja yang dimanfaatkan dengan cara produktif, seperti: persawahan dan swalayan. ${ }^{23}$ Meskipun sebagaian tanah wakaf telah dikelola secara produktif, seperti persawahan dan swalayan, tetapi dalam pengelolaannya tidak ditangani oleh majelis wakaf, seperti swalayan dan koperasi di Kecamatan Tempurejo yang dikelola oleh Yayasan Baitul Hikmah, serta persawahan seluas sekitar 11 hektar dikelola oleh Yayasan Al-Ikhwaniyah Kecamatan Gumukmas, dan madrasah di Kecamatan Jombang yang ditangani oleh perorangan. Sehingga fungsi pemanfaatan wakaf untuk kesejahteraan masyarakat belum optimal. ${ }^{24}$

Sayang sekali aset wakaf yang begitu banyak dan potensial, pada umumnya pemanfaatannya masih bersifat konsumtif-

22 Yusfi Hadi, Ketua Yayasan Baitul Hikmah Tempurejo, wawancara, (tanggal 26 Januari 2017).

${ }^{23}$ Adnan Widodo, Kepala KUA Jombang, wawancara, (tanggal 19 Januari 2017).

24 Observasi di Yayasan Baitul Hikmah Kecamatan Tempurejo, Yayasan AlIkhwaniyah Gumukmas, dan masjid Darul Falah Kecamatan Jombang Kabupaten Jember, (tanggal 02-15 Februari 2017). 
tradisional dan belum dikelola secara produktif, sehingga belum menyentuh dan terasa manfaatnya secara optimal bagi kesejahteraan masyarakat. Dan sedikit sekali tanah wakaf yang dikelola secara produktif dalam bentuk suatu usaha yang hasilnya dapat dimanfaatkan bagi pihak-pihak yang memerlukan, termasuk fakir dan miskin. Pemanfaatan wakaf untuk kepentingan masjid, pesantren, dan madrasah jika dilihat dari segi sosial, khususnya untuk kepentingan keagamaan memang efektif, tetapi dampaknya kurang berpengaruh dalam kehidupan ekonomi masyarakat.

Sebenarnya, meskipun pemanfaatan wakaf tetap berorientasi untuk kepentingan masjid, tetapi seyogyanya menggunakan pola pengelolaan ke arah yang lebih produktif. Munawir mengemukakan model yang komprehensif tentang masjid: Pertama, mengembalikan fungsi masjid sebagaimana zaman awal Islam dengan harapan kejayaan Islam dapat tercapai; Kedua, membiarkan masjid seperti yang ada saat ini, tetapi dengan memperkuat peran dan fungsi masjid yang sudah ada secara maksimal dalam bentuk dikotomis dan terpisah; dan Ketiga, mengakomodir dengan paling tidak menghidupkan kemabli aspek ibadah dan juga memperhatikan fungsi sosial ekonominya. ${ }^{25}$

Begitu pula hasil penelitian Miftahul Huda, yang menggali tentang model kemandirian masjid berbasis wakaf di Masjid Besar Imam Ulomo Sampung Ponorogo, menemukan bahwa pola atau model kemandirian masjid berbasis wakaf yang diterapkan adalah kemandirian aset dengan mengembangkan aset-aset wakaf masjid secara produktif baik di bidang pertanian, perikanan, maupun lainnya. Namun, pola kemandirian dari sisi penguatan kapasitas nâzhir belum maksimal mengingat nâzhir yang dikembangkan adalah masih dalam kluster nâzhir perorangan. Sedangkan, pola kemandirian dari sisi manfaat hasil wakaf yang diperuntukkan tidak hanya kepentingan masjid tetapi juga kepentingan jamaah masyarakat sekitar yang membutuhkan. ${ }^{26}$

25 M. Fajrul Munawir, "Fungsi Majid Antara Realita dan Idealita" dalam Fakultas Dakwah UIN Yogyakarta, Model-model Kesejahteraan Sosial Islam, (Yogyakarta, UIN Sunan Kalijaga, 2007),. 141-142.

26 Miftahul Huda, "Kemandirian Berbasis Wakaf di Masjid Besar Imam Ulomo Sampung Ponorogo", dalam Al-Ihkam, Vol. 12, No. 2, (Desember 2017), hlm. 362. 
Pengelolaan wakaf memiliki perbedaan dengan pengelolaan zakat ataupun sedekah pada umumnya. Pengelola wakaf diutamakan untuk menjaga agar harta wakaf tetap utuh namun dikembangkan supaya memberikan hasil yang maksimal kepada mauquf alaih. Sementara pengelolaan zakat, amil dapat mendistribusikan semua harta zakat yang terkumpul kepada mustahiq. Oleh karena itu, bentuk dan manajemen pengelolaan wakaf berbeda dengan zakat. ${ }^{27}$

Dibandingkan zakat dan sedekah pada umumnya, wakaf memiliki beberapa kelebihan, antara lain: (1) memberikan pahala yang berkesinambungan kepada pembayarnya secara berterusan walaupun kepemilikannya sudah berpindah dan pembayarnya sudah meninggal dunia; (2) merupakan wujud konkrit kemandirian masyarakat Islam dalam menciptakan kesejahteraan dan solidaritas sosial diantara mereka; (3) salah satu cara melestarikan pokok harta dari kemusnahan; (4) menjadikan manfaat harta wakaf dapat dirasakan oleh generasi mendatang, dan (5) bermanfaat bagi orangorang yang berhak untuk memenuhi kebutuhan mereka. Jika zakat ditujukan untuk menjamin keberlangsungan pemenuhan kebutuhan pokok kepada 'delapan golongan' penerima, maka wakaf lebih dari itu. Hasil pengelolaan wakaf dapat dimanfaatkan oleh 'semua lapisan masyarakat', tanpa batasan golongan untuk kesejahteraan umat. ${ }^{28}$

Untuk itulah Undang-Undang No. 41 Tahun 2004 tentang Wakaf dirumuskan untuk menggerakkan seluruh potensi wakaf yang ada di tanah air secara produktif bersamaan dengan laju perubahan struktur masyarakat modern yang lebih banyak bertumpu pada sektor industri. Wakaf harus dikembangkan secara optimal dengan pengelolaan profesional produktif untuk mencapai hasil yang nyata dalam kehidupan masyarakat banyak. Sehingga wakaf tidak berhenti menjadi harta kekayaan umat Islam yang 'mandek' dengan segala problematikanya yang ruwet.

Untuk saat ini, pengelolaan tanah wakaf untuk tujuan produktif belum dapat terlaksana secara maksimal. Masih banyak tanah-tanah wakaf yang kosong dan terbengkalai yang belum sepenuhnya

27 Rahmat Dahlan, "Analisis Kelembagaan Badan Wakaf Indonesia”, Esensi: Jurnal Bisnis dan Manajemen, Vol. 6, No. 1, (April 2016),. 116.

28 Ekawaty, Marlina dan Anggi Wahyu Muda, "Wakaf Uang: Tingkat Pemahaman Masyarakat \& Faktor Penentunya (Studi Masyarakat Muslim Kota Surabaya, Indonesia”, Jurnal Iqtishoduna Vol. 11, No. 2, (Juli 2015),. 2. 
digarap oleh nâzhir di Kabupaten Jember. Contohnya, areal tanah wakaf di daerah strategis dapat dibuat pertokoan, di sekitar daerah pelayanan publik dibuat tempat parkir, dan di daerah pedesaan dapat ditanami pohon jati atau areal persawahan, dan sebagainya. Sebagaimana yang telah diterapkan oleh Yayasan Baitul Hikmah Tempurejo yang mengelola tanah wakaf yang awalnya tidak dimanfaatkan menjadi swalayan dan koperasi. Pendanaan untuk membangun dan modal awal diberi bantuan oleh Kementerian Agama. Namun, bentuk wakaf produktif yang berupa swalayan dan koperasi seperti ini hanya ada satu di Kabupaten Jember. Bentuk wakaf produktif di kecamatan lain masih berupa persawahan dan perkebunan. Salah satu faktor penyebab hal ini terjadi karena kurang pahamnya para nâzhir untuk menyerap bantuan dari pemerintah, khususnya Kementerian Agama. ${ }^{29}$

Tanah wakaf yang ada di Kabupaten Jember cukup banyak dan tersebar di seluruh kecamatan, sehingga terkadang tidak bisa dihindari lagi mengalami beberapa konflik atau sengketa dengan pihak-pihak tertentu. Jumlah sengketa tanah wakaf di Kabupaten Jember masih relatif sedikit. Sengketa yang dialami kebanyakan terjadi dengan ahli waris wâqif dengan nâzhir setelah si wakif meninggal, atau dengan anggota masyarakat yang mengaku pemilik sah dari tanah wakaf tersebut. Misalnya, bentuk sengketa itu, si wakif mempunyai tanah seluas 1000 meter dengan 1 sertifikat utuh, kemudian ia mewakafkan sebagian tanah itu seluas 300 meter. Suatu ketika si wakif meninggal dunia, hingga ahli warisnya menuntut kembali tanah yang telah diwakafkan itu dengan dalih ia mempunyai bukti sertifikat utuh. ${ }^{30}$

Meskipun sering terjadi sengketa tanah wakaf, sampai saat ini belum pernah penyelesaian persengketaan tersebut sampai dibawa ke Pengadilan Agama, biasanya dapat diselesaikan secara kekeluargaan. Apabila melalui jalan kekeluargaan tidak juga ditemukan jalan keluar dalam persengketaan tanah wakaf, biasanya dari pihak nâzhir sendiri akan mengikhlaskan tanah wakaf tersebut untuk diakui oleh si ahli

29 Yusfi Hadi, Ketua Yayasan Baitul Hikmah Tempurejo, wawancara, (tanggal 26 Januari 2017)

30 Syamsul Arifin, Nadzir di Kecamatan Jombang, wawancara, (tanggal 2 Februari 2017) 
waris. Hal ini dilakukan karena biasanya tanah-tanah wakaf yang menjadi sengketa tersebut, dari nâzhir sendiri tidak mempunyai bukti seperti sertifikat tanah wakaf atau ikrar wakaf yang menyatakan bahwasanya tanah-tanah wakaf tersebut memang tanah wakaf yang dikuasai oleh nâzhir. ${ }^{31}$

Sengketa tanah wakaf ini seharusnya diselesaikan melalui Badan Wakaf Indonesia (BWI) sebagai mediator diantara pihak-pihak yang mengalami konflik. Namun, sampai saat ini belum dibentuk BWI di Kabupaten Jember. Ironis jika tanah wakaf yang sifatnya permanen untuk selama-lamanya berubah kembali pada ahli waris karena belum ada sertifikat tanah dan belum adanya mediator berupa BWI.

Dengan demikian, pembentukan BWI di Kabupaten Jember merupakan suatu keniscayaan. Jika BWI di Kabupaten Jember nantinya telah dibentuk, maka sinergitas antar lembaga wakaf dapat tercipta sehingga tata kelola wakaf dapat diimplementasikan secara maksimal. Karena sinergitas yang kuat antara nâzhir, Kementerian Agama, BWI, wakif, dan aparat penegak wakaf lain, seperti: Pejabat Pembuat Akta Ikrar Wakaf (PPAIW), juga bisa saling bekerjasama agar pengelolaan wakaf dapat berjalan secara maksimal. Sebagai badan atau lembaga yang berwenang dan lebih besar pengaruhnya, BWI-lah yang mempunyai peran penting dalam perwakafan di Indonesia, lembaga tersebut harus punya andil dan mengambil bagian yang besar dalam pola perwakafan. Lembaga tersebut punya peran sentral terhadap aparat penegak wakaf seperti: nâzhir, wâqif dan aparat yang lainnya. BWI dapat melakukan langkah-langkah seperti: membina, memberikan pelatihan, pemahaman terhadap nâzhir ataupun wakif serta membantu segala bentuk pembiayaan yang dibutuhkan nâzhir dalam mengelola harta untuk menunjang kepengelolaan dan kemudian BWI harus mengawasi segala bentuk aktivitas kepengelolaan yang terjadi.

\section{Faktor Penghambat Tata Kelola Wakaf di Kabupaten Jember}

Faktor penghambat yang dihadapi dalam perwakafan tanah di Kabupaten Jember berdasarkan hasil penelitian antara lain:

${ }^{31}$ Khoiri, Nadzir di Kecamatan Gumukmas, wawancara, (tanggal 22 Januari 2017) 
Abd. Syakur, dkk.

Hambatan ditinjau dari segi wakif, yaitu: Pertama, pada umumnya setelah wakif meninggal dunia, ahli waris dari wakif tidak sesegera mungkin menyerahkan berkas-berkas tentang perwakafan tanah yang dimiliki oleh ahli waris wakif tersebut ke pihak Pejabat Pembuat Akta Ikrar Wakaf (PPAIW), dengan anggapan bahwa tanah yang sudah diwakafkan hubungannya adalah dengan Allah SWT sehingga tidak mungkin diselewengkan, oleh karenanya dianggap bukti tertulis mengenai perwakafan tanah tersebut tidak diperlukan lagi dalam hal ini; Kedua, terjadi ketidaksesuaian kehendak antara wakif dengan nâzhir, misalnya wakif menginginkan pergelolaan wakaf seperti ini, sedangkan pihak masyarakat menghendaki nâzhir melakukan pengelolaan dengan cara yang berbeda dengan kehendak wakif. Sehingga atas dasar hal tersebut wakif kemudian tetap menguasai bukti tertulis atas perwakafan tanah itu; Ketiga, adanya seorang nâzhir yang telah meninggal dunia, kemudian digantikan oleh ahli warisnya tetapi tidak segera melakukan perubahan dalam sertifikasi wakaf, sehingga kemudian dianggap tanah wakaf tersebut sebagai waris turun-temurun.

Hambatan ditinjau dari status tanah wakaf, yaitu: Pertama, jumlah tanah wakaf di Kabupaten Jember mencapai 141,06 hektar, dan 116,93 hektar diantaranya belum tersertifikasi, bahkan belum melakukan Akta Ikrar Wakaf (AIW) ke Pejabat Pembuat Akta Ikrar Wakaf (PPAIW) dikarenakan tidak adanya dana untuk pengurusan sertifikasi tanah wakaf; ${ }^{2}$ Kedua, terdapat ketidak-konsistenan antara prosedur yang ada di KUA, Kementerian Agama, dan BPN, yang menyebabkan para nâzhir yang mengurusi pengajuan sertifikat tanah wakaf mengalami kebingunan bahkan ada yang merasa putus asa, sehingga tanah wakaf dibiarkan terbengkalai tanpa sertifikat. ${ }^{33}$

Hambatan ditinjau dari segi nâzhir, yaitu: Pertama, pada umumnya nâzhir tidak maksimal mengelola tanah-tanah wakaf itu, karena kebanyakan kemampuan dan pemahaman masyarakat yang menganggap wakaf hanya identik dengan tempat ibadah, padahal dalam UU No. 41 Tahun 2004 dijelaskan wakaf tidak hanya ditujukan sebagai tempat ibadah saja, tetapi lebih mengarah ke pemberdayaan

\footnotetext{
32 Abdullah, Kabid. Wakaf di KUA Jombang, wawancara, (tanggal 19 Januari 2017)

33 Yusfi Hadi, Ketua Yayasan Baitul Hikmah Tempurejo, wawancara, (tanggal 26 Januari 2017)
} 
wakaf produktif untuk pengembangan ekonomi umat; 34 Kedua, para nâzhir yang sibuk dengan pekerjaan masing-masing, sehingga menjadikan pengelolaan tanah wakaf yang produktif menjadi tertunda atau terabaikan; ${ }^{35}$ Ketiga, kurangnya modal untuk mengelola tanah menjadi produktif. Meskipun tanah wakaf yang terdapat di Kabupaten Jember itu luas, namun jika modal awal untuk mengelolanya kurang maka pengelolaan wakaf produktif tidak akan terlaksana dengan maksimal. ${ }^{36}$

Hambatan ditinjau dari segi kebijakan dan birokrasi, yaitu: Pertama, pihak Kementerian Agama Kabupaten Jember yaitu kurangnya mensosialisasikan UU No. 41 tahun 2014 dan PP No. 42 Tahun 2006, khususnya pentingnya pengelolaan wakaf produktif kepada lembaga wakaf dan masyarakat; ${ }^{37}$ Kedua, pihak Kantor Pertanahan sendiri sama sekali tidak ada toleransi untuk tanah wakaf yang bentuknya masih belum sertifikat, sehingga dalam hal ini harus tetap diproses seperti tanah biasa meskipun sudah ada AIW-nya;38 Ketiga, ketidak-pahaman pihak-pihak dalam menjalankan prosedur sertifikasi tanah wakaf tersebut. Padahal peranan dari PPAIW sangat tinggi dalam rangka penerbitan sertifikat wakaf sehingga tanah wakaf tersebut mempunyai jaminan kepastian hukum. PPAIW bukan saja menyiapkan dokumen atau administrasi saja sebagai kelengkapan untuk mengajukan permohonan pendaftaran sertifikat wakat tetapi pejabat yang dianggap mempunyai kompetensi untuk mewujudkan jaminan kepastian hukum;39 Keempat, tidak semua nâzhir adalah orang-orang yang paham tentang prosedur wakaf. Begitu nâzhir menerima harta benda wakaf, yang dipahami hanya mengelola begitu

\footnotetext{
${ }^{34}$ Abdullah, Kabid. Wakaf di KUA Jombang, wawancara, (tanggal 19 Januari 2017).

35 Kiai Sudar, Yayasan Al-Ikhwaniyah Gumukmas, wawancara, (tanggal 02 Februari 2017).

36 Yusfi Hadi, Ketua Yayasan Baitul Hikmah Tempurejo, wawancara, (tanggal 26 Januari 2017).

37 Adnan Widodo, Kepala KUA Jombang, wawancara, (tanggal 19 Januari 2017).

38 Abdullah, Kabid. Wakaf di KUA Jombang, wawancara, (tanggal 19 Januari 2017).

39 Prosedur pendaftaran harta benda wakaf ini secara detail dapat dilihat dalam UU RI No. 41 Tahun 2004 tentang Wakaf Pasal 32-37; Peraturan Pemerintah No. 42 Tahun 2006 Pasal 38-44; dan Surat Keputusan Bersama Menteri Agama dan Kepala BPN No. 422 dan No. 3/SKB/2004 tentang Sertifikat Tanah Wakaf; atau lihat Abdul Ghofur Anshori, Hukum dan Praktek Perwakafan di Indonesia, (Yogyakarta: Pilar Media, 2006), . 83-84
} 
saja. Bisa jadi nâzhir juga tidak memahami antara hak dan kewajiban; ketentuan yang dibolehkan dan dilarang. Sedangkan penentuan nâzhir adalah hak mutlak dari wâqif.

Hambatan ditinjau dari segi kesadaran masyarakat, yaitu: Pertama, kesadaran masyarakat yang rendah untuk melakukan kegiatan pengelolaan perwakafan secara transparan dengan melibatkan masyarakat secara luas. Dari pihak Kementerian Agama juga kekurangan tenaga penyuluh ke masalah-masalah yang berkaitan dengan masalah perwakafan; 40 Kedua, adanya ketidakpatuhan terhadap kebijakan yang berlaku. UU RI No. 41 Tahun 2004 dan PP No. 42 Tahun 2006 justru dianggap bermasalah karena banyak pengelola wakaf dan masyarakat yang mempunyai pemahaman yang salah kaprah, yang menganggap bahwa wakaf hanya berkaitan dengan urusan peribadatan, tidak boleh dimanfaatkan di luar ikrar awal, dan wakaf produktif bertentangan dengan hukum syari'ah salaf atau tradisional. Sehingga yang muncul justru ketidak-patuhan dan daya tanggap yang kurang dari masyarakat yang malah menciptakan konflik.

Minimnya pelibatan pemimpin/tokoh lokal oleh pemerintah dapat berakibat pada terhambatnya implementasi kebijakan tata kelola wakaf. Kepercayaan dan kepatuhan masyarakat terhadap tokoh lokal ini merupakan salah satu bentuk kearifan lokal. Kearifan lokal biasanya tercermin dalam keyakinan dan kebiasaan hidup masyarakat yang telah berlangsung lama. Keberlangsungan kearifan lokal akan tercermin dalam nilai-nilai yang berlaku dalam kelompok masyarakat tertentu. Nilai-nilai itu menjadi pegangan kelompok masyarakat yang biasanya akan menjadi bagian hidup tak terpisahkan yang dapat diamati melalui sikap dan perilaku seharihari. ${ }^{41}$

Dengan demikian tampak, tampak bahwa variabel yang sangat mempengaruhi keberhasilan tata kelola wakaf yaitu adanya peran kiai/pemimpin/tokoh lokal pengelola wakaf yang dapat dipercaya, kreatif, dan profesional. Jika dikaitkan dengan variabel kontek

\footnotetext{
40 Yusfi Hadi, Ketua Yayasan Baitul Hikmah Tempurejo, wawancara, (tanggal 26 Januari 2017).

${ }^{41}$ Abdul Hakim, "Kearifan Lokal dalam Ekonomi Islam (Studi Atas Aplikasi al-Urf Sebagai Dasar Adopsi)", Jurnal AKADEMIKA, Vol. 8, No. 1, (Juni 2014), 70
} 
implementasi kebijakan (context of implementation) menurut Grindle ${ }^{42}$, maka terdapat kelemahan dari Teori Grindle tersebut karena ia tidak menyebutkan secara eksplisit bahwa faktor kearifan lokal berupa pemimpin lokal yang dapat mempengaruhi keberhasilan implementasi kebijakan. Padahal meningkatnya aset tanah wakaf di Kabupaten Jember dari tahun ke tahun, disebabkan para pemberi wakaf mau mewakafkan tanahnya karena masih memandang seorang pemimpin/tokoh lokal yang mereka anggap dapat dipercaya, serta dapat mendatangkan barokah dan keselamatan.

\section{Alternatif Solusi untuk Mengatasi Hambatan Tata Kelola Wakaf}

Meskipun model yang digunakan dalam pengelola tanah wakaf di Kabupaten Jember memang mulai merambah pada berbagai bidang, tetapi pengelolaannya masih belum berhasil menjadikan hasil dari pengembangan tanah wakaf secara finansial. Hambatan yang ekstrim yaitu pada umumnya (a) nâzhir tidak maksimal mengelola tanah-tanah wakaf karena pemahaman terbatas yang menganggap wakaf hanya identik dengan tempat ibadah, (b) nâzhir menjalankan tugasnya hanya sebagai tugas sampingan, (c) pengangkatan nâzhir hanya didasarkan kepercayaan saja, (d) pelatihan nâzhir tidak secara menyeluruh, (e) pengawasan yang kurang intensif, dan (f) nâzhir tidak melakukan pelaporan kegiatan secara rutin.

Manajemen lembaga wakaf menjadi bagian yang paling krusial dalam memahami persoalan wakaf. Manajemen wakaf berkaitan dengan nâzhir selaku pengelola wakaf, sistem pengelolaan wakaf, dan akuntabilitasnya. Hasil penelitian yang dilakukan oleh Kasdi, menunjukkan bahwa sebagian besar lembaga wakaf dikelola oleh perseorangan (66\%) dan selebihnya dikelola oleh nâzhir organisasi dan badan hukum. Dibandingkan nâzhir wakaf perseorangan, dalam berbagai aspek, ditemukan bahwa pengelolaan wakaf berbasis organisasi dan badan hukum secara umum lebih memungkinkan untuk diupayakan ke arah pengembangan wakaf. Hal ini disebabkan adanya fakta di mana mayoritas pengelola wakaf yang notabene nâzhir perseorangan bekerja paruh waktu (84\%) dan tidak mendapat

42 Grindle, Politics and Policy Implementation, 6-10. 
imbalan. Di samping itu, pola penunjukan nâzhir yang dominan adalah berdasarkan unsur kekerabatan. ${ }^{43}$

Kegagalan pada tingkat nâzhir itu disebabkan oleh buruknya sistem manajemen yang dapat dilihat dari buruknya implementasi prinsip-prinsip Good Corporate Governance (GCG) yang terdiri dari: Transparansi, Akuntabilitas, Responsibilitas, Independensi, dan Fairness. ${ }^{44}$ Temuan senada juga diungkapkan oleh Mardian dalam penelitiannya bahwa dalam konteks GCG dalam perspektif syariah Islam, pemenuhan prinsip syariah menjadikan konsep GCG yang lebih luas dari GCG konvensional. Dalam Islam, kepentingan utama yang lebih utama adalah penjagaan Islam itu sendiri. Dengan kata lain, konsep GCG dalam Islam lebih komprehensif dari Franco German Model. ${ }^{45}$

Ekspektasi yang tinggi dari stakeholders terhadap lembaga wakaf dapat dimaklumi mengingat besarnya aset wakaf yang dimiliki. Namun pengelolaan yang tidak baik dapat meruntuhkan ekspektasi tersebut sehingga menimbulkan gejolak dan kontroversi. Temuan di lapangan menunjukkan bahwa besarnya aset wakaf tidak serta merta menjadikan lembaga wakaf itu berhasil mewujudkan misinya sebagai lembaga yang bergerak dalam bidang pemberdayaan. Maka setiap nâzhir (baik perseorangan, organisasi, maupun badan hukum) harus siap diaudit secara berkala oleh akuntan publik dan diawasi oleh lembaga pengawasan yang independen dan masyarakat. Pengawasan yang bersifat internal sudah menjadi keharusan, bersamaan dengan kepedulian masyarakat sekitar untuk mengawasi kinerja nâzhir.

Mesir sekiranya dapat dijadikan sebagai percontohan tata kelola wakaf yang baik. Mesir adalah negara yang terhitung sukses dalam pengelolaan wakafnya. ${ }^{46}$ Usaha pertama yang dilakukan oleh pemerintah Mesir adalah menertibkan tanah wakaf melalui penjagaan dan pemeliharaan serta diarahkan pada tujuan kemaslahatan umum. Selain itu, pemerintah juga memberikan perlindungan kepada para

43 Abdurrahman Kasdi, "Peran Nadzir dalam Pengembangan Wakaf", Jurnal Zakat dan Wakaf, dalam journal.stainkudus.ac.id, (Juni, 2016), 215

44 KNKG, Pedoman Umum Good Corporate Governance Indonesia, 34-45.

45 Sepky Mardian, "Studi Eksplorasi Pengungkapan Penerapan Prinsip Syariah (Sharia Compliance) di Bank Syariah", SEBI Islamic Economics \& Finance Journal, Vol 4, No. 1, (Februari, 2011), 5.

${ }^{46}$ Muhammad Qadr Basa, Qanûn al-Adl wa al-Inshaf fi al-Qadla' ala Musykilât al-Awqâf, (Kairo: Dâr as-Salâm, 2006), 21. 
mustahiq. Langkah selanjutnya yang dilakukan pemerintah adalah membentuk dîwân al-waqf yang menjadi cikal bakal Kementerian Wakaf. ${ }^{47}$

Pengelolaan wakaf di Mesir sudah mengarah kepada pemberdayaan ekonomi. Sinergitas antara pemerintah, badan wakaf, perusahaan, bank, perguruan tinggi, dan lembaga terkait lain benarbenar dilaksanakan dengan baik. Badan Wakaf Mesir membuat beberapa kebijakan seperti menitipkan harta wakaf di bank Islam, mengadakan kerjasama dengan perusahaan-perusahaan bonafide, mengelola tanah-tanah kosong secara produktif bahkan membeli saham dan obligasi perusahaan yang kokoh. ${ }^{48}$ Bahkan, dengan harta wakaf yang dimiliknya, Universitas al-Azhar Kairo memberikan beasiswa bagi ribuan mahasiswanya. Selain itu, juga menerbitkan kitab agama dan buku lainnya secara gratis. Al-Azhar selaku nâzhir atau pengelola wakaf hanya mengambil hasilnya untuk keperluan pendidikan. ${ }^{49}$

Sedangkan, perwakafan di Indonesia yang sebenarnya lebih potensial malah jauh tertinggal dibanding negara-negara yang mayoritas berpenduduk Islam lain, seperti Mesir, Aljazair, Arab Saudi, Kuwait, dan Turki. Mereka jauh-jauh hari sudah mengelola wakaf ke arah produktif. Bahkan, di negara yang penduduk muslimnya minor, seperti Singapura, aset wakafnya jika dikruskan sekitar S\$ 250 juta. Untuk mengelolanya, Majelis Ugama Islam Singapura (MUIS) membuat anak perusahaan bernama Wakaf Real Estate Singapura (WAREES). ${ }^{50}$

\section{Penutup}

Tata kelola wakaf di Kabupaten Jember memang telah disesuaikan dengan UU No. 41 tahun 2004 dan pedoman-pedoman

${ }^{47}$ Uswatun Hasanah, "Peranan Wakaf dalam Mewujudkan Kesejahteraan Sosial (Studi Kasus Pengelolaan Wakaf di Jakarta Selatan)", (Disertasi, IAIN Syarif Hidayatullah, 1997), 81.

${ }^{48}$ Hasanah, Peranan Wakaf, 81.

${ }^{49}$ A. Chairul Hadi, "Peluang Wakaf Produktif untuk Pembiayaan Pendidikan Islam", Jurnal TURATS, Vol. 5, No. 1, (Juni, 2009), 17.

50 Nur Kholis, "Wakaf dan Upaya Pemberdayaan Potensinya Secara Produktif di Indonesia“, dalam Pribumisasi Hukum Islam, (Yogyakarta: PPsFIAI UII, 2012), 491. 
yang ada, namun belum sepenuhnya terlaksana dengan baik. Faktor penghambat perwakafan tersebut diantaranya: belum dibentuknya BWI di Kabupaten Jember; ego ahli waris dari wâqif yang ingin menguasai tanah wakaf dan merasa tidak cocok dengan nâzhir; sistem pengangkatan dan pergantian nâzhir yang kurang prosedural; terdapat ketidak-konsistenan prosedur antar lembaga terkait pengurusan sertifikat tanah wakaf; nâzhir masih kurang professional dan nâzhir menjalankan tugasnya hanya sebagai tugas sampingan; kurangnya sosialisasi kebijakan wakaf kepada para nâzhir dan masyarakat; dan diperparah dengan ketidak-patuhan sebagian masyarakat terhadap kebijakan wakaf yang dirumuskan pemerintah karena pemahaman yang rendah terkait pentingnya wakaf produktif.

Eksistensi wakaf dalam konstalasi sosial masyarakat sangat didambakan, sebab lembaga wakaf hakikatnya bukan hanya sebagai 'shock breaker' untuk menanggulangi kebutuhan sesaat, melainkan diharapkan sebagai sub-sistem lembaga keuangan lainnya. Wakaf jika dikelola secara profesional akan merupakan sumber dana yang potensial untuk pembangunan bangsa dan negara. Oleh karena itu, setiap nâzhir perlu mewujudkan Good Waqf Governance dengan menerapkan prinsip-prinsip Good Corporate Governance (GCG) berbasis Islam, karena GCG konvensional saja tidak cukup apabila tidak didukung dengan pelaku-pelaku yang jujur dan amanah.

\section{Daftar Pustaka}

Anshori, Abdul Ghofur, Hukum dan Praktek Perwakafan di Indonesia, Yogyakarta: Pilar Media, 2006.

Basa, Muhammad Qadr, Qanûn al-`Adl wa al-Inshaf fi al-Qadla' ala Musykilât al-Awqâf, Kairo: Dâr as-Salâm, 2006.

Bromley, Daniel, Economic Interests and Institutions, New York: Basil Blackwell, 1989.

Grindle, Merilee S., Politics and Policy Implementation in the Third World, New Jersey: Princeton University Press, 1980.

Kholis, Nur, "Wakaf dan Upaya Pemberdayaan Potensinya Secara Produktif di Indonesia", dalam Pribumisasi Hukum Islam, Yogyakarta: PPs-FIAI UII, 2012.

Komite Nasional Kebijakan Governance (KNKG), Pedoman Umum Good Corporate Governance Indonesia, Jakarta: KNKG, 2006. 
Miles, Matthew B., A. Michael Huberman, and Johnny Saldana, Qualitative Data Analysis, A Methods Sourcebook, Sage Publications, Inc., 2014.

Miles, Matthew B., and A. Michael Huberman, Analisis Data Kualitatif: Buku Sumber Tentang Metode-metode Baru, (Terj.) Tjetjep Rohendi Rohidi, Jakarta: UI-Press, 1992.

Munawir, M. Fajrul, "Fungsi Majid Antara Realita dan Idealita" dalam Fakultas Dakwah UIN Yogyakarta, Model-model Kesejahteraan Sosial Islam, (Yogyakarta, UIN Sunan Kalijaga, 2007.

Setiawan, Budi Utomo, Figh Aktual, (Jakarta: Gema Insani Press, 2004)

Sugiyono, Metode Penelitian Kuantitatif, Kualitatif Dan RED, Bandung: Alfabeta, 2008.

Tanguilisan, Hessel Nogi S., Teori dan Konsep Kebijakan Publik, Yogyakarta: Ar-Ruzz Media, 2004.

Tariqi, Abdullah Abdul Husain, Ekonomi Islam: Prinsip, Dasar dan Tujuan, Yogyakarta: Magistra Insania Press, 2004.

Zarkasyi, W., Good Corporate Governance Pada Badan Usaha Manufaktur, Perbankan, dan Jasa Keuangan Lainnya, Bandung: Alfabeta, 2008.

Dahlan, Rahmat, "Analisis Kelembagaan Badan Wakaf Indonesia", ESENSI: Jurnal Bisnis dan Manajemen, Vol. 6, No. 1, (April, 2016).

Ekawaty, Marlina dan Anggi Wahyu Muda, "Wakaf Uang: Tingkat Pemahaman Masyarakat \& Faktor Penentunya (Studi Masyarakat Muslim Kota Surabaya, Indonesia", Jurnal IQTISHODUNA Vol. 11, No. 2, (Juli, 2015).

Hadi, A. Chairul, "Peluang Wakaf Produktif untuk Pembiayaan Pendidikan Islam", Jurnal TURATS, Vol. 5, No. 1, (Juni, 2009).

Hadi, Abu Azam. “Upaya Pemberdayaan Tanah Wakaf Produktif Bagi Kesejahteraan Ummat," Jurnal ISLAMICA, Vol. 4 No. 1, (September, 2009).

Hakim, Abdul. "Kearifan Lokal dalam Ekonomi Islam (Studi Atas Aplikasi al-Urf Sebagai Dasar Adopsi)", Jurnal AKADEMIKA, Vol. 8, No. 1, (Juni, 2014).

Huda, Miftahul. "Kemandirian Berbasis Wakaf di Masjid Besar Imam Ulomo Sampung Ponorogo", dalam AL-IHKAM, Vol. 12, No. 2, (Desember, 2017). 
Abd. Syakur, dkk.

Hariyanto, Erie, dan Ni'matunnuriyah. "Advokat Syariah dalam Mediasi Perkara Perceraian Menurut Maqashid Al Syariah." ULUL ALBAB Jurnal Studi Islam Vol 18, No. 1 (31 Juli 2017).

Kasdi, Abdurrahman, "Peran Nâzhir dalam Pengembangan Wakaf", Jurnal Zakat dan Wakaf, dalam journal.stainkudus.ac.id, (Juni, 2016).

Mardian, Sepky, "Studi Eksplorasi Pengungkapan Penerapan Prinsip Syariah (Sharia Compliance) di Bank Syariah", SEBI Islamic Economics \& Finance Journal, Vol 4, No. 1, (Februari, 2011).

Hasanah, Uswatun, "Peranan Wakaf dalam Mewujudkan Kesejahteraan Sosial (Studi Kasus Pengelolaan Wakaf di Jakarta Selatan)", (Disertasi, IAIN Syarif Hidayatullah, 1997).

Lia Kurniawati, "Penarikan Wakaf Tanah oleh Ahli Waris (Studi Kasus di Kelurahan Manding Kecamatan Temanggung)", (Tesis, STAIN Salatiga, 2012).

Winajat, Uden, "Sertifikasi Tanah Wakaf di Kecamatan Warungkondang Kabupaten Cianjur", (Tesis, STAIN Salatiga, 1996).

BWI, “Tantangan Wakaf untuk Keadilan Sosial”, 2 Desember 2008, https://bwi.or.id/index.php/ar/publikasi/berita-mainmenu109/346-tantangan-wakaf-untuk-keadilan-sosial.html, (diakses tanggal 23 Februari 2018).

Direktorat Pemberdayaan Zakat dan Wakaf Kemenag RI, “Jumlah Tanah Wakaf Seluruh Indonesia", http://siwak.kemenag.go.id/tabel_jumlah_tanah_wakaf.php, (diakses tanggal 22 Februari 2018).

Direktorat Pemberdayaan Zakat dan Wakaf Kementerian Agama RI, "Jumlah Tanah Wakaf Seluruh Indonesia", http:/ / siwak.kemenag.go.id/tanah_wakaf_kab.php?prov=35\& $\underline{\mathrm{kab}=09}$, (diakses tanggal 22 Februari 2018). 